\title{
TCOM \\ Science in the media: the scientific community's perception of the COVID-19 media coverage in Spain
}

\section{Javier de Sola Pueyo}

\begin{abstract}
The COVID-19 pandemic was the most prominent feature in the media in 2020. This research analyzes the scientific community's perception of the journalistic coverage of the pandemic in the Spanish media. Based on a survey with the participation of 818 respondents, the study revealed that scientists believe that radio did the best job in reporting the pandemic, whereas television did the worst. Among our findings, it is worthwhile to mention that - according to scientists - the media used sensationalistic tones and reports were not particularly accurate nor realistic. Finally, we included the scientific community's recommendations to treat the subject more appropriately.
\end{abstract}

Keywords

DOI

Health communication; Participation and science governance; Science and media

https://doi.org/10.22323/2.20020208

Submitted: 26th October 2020

Accepted: 12th January 2021

Published: 6th April 2021

Introduction

In terms of media coverage, 2020 was substantially monopolized by the COVID-19 pandemic, the most prominent feature in the news of the year. In dealing with the pandemic, the information overload and fake news [Pérez-Dasilva, Meso-Ayerdi and Mendiguren-Galdospín, 2020] reinforced the concept of "infodemic" in referring to the overabundance of information, sometimes not accurate, that creates difficulties for society to understand which resources to use to access reliable information [Hua and Shaw, 2020]. The term "infodemic" was even used by the World Health Organization in the past month of February: "We are not only fighting an epidemic but also an infodemic" [Adhanom, 2020].

The concerns about misinformation on the pandemic led to several studies in recent months and - something that is less common - a huge number of editorials and opinion articles in the most prestigious scientific journals [Depoux et al., 2020; Garrett, 2020] written by experts who invited the media to act with extreme responsibility. 
Therefore, the role of the media became, if possible, a more relevant issue in this context than in an ordinary scenario. Above all, it is even more so in light of the aforementioned fake news, and the public health and healthcare issues that it can cause [Salaverría et al., 2020]. Fake news has turned into a generalized trend in the social networks over the past few months [Radu, 2020]. "The news provided and shared through Facebook can be described as 'too simplistic', which has a negative effect on the narrative of the crisis and does not produce uniform discursive narratives", Papa and Maniou [2020, p. 23] warned in their study.

The effects of communication and the role played by the media in reporting on a pandemic or, more generally, a health crisis situation, were recently studied in an extensive manner [Ophir, 2019; Pieri, 2019; Qiu and Chu, 2019] both from the perspective of public institutions and press offices as well as news outlets.

Based on the above, it can be said that "effective scientific communication and open access have allowed for early recognition and control of diseases that may even become pandemics" [Arteaga-Livias and Rodriguez-Morales, 2020, p. 7]. As early as March 2020, the Asociación Española de Comunicación Científica (AECC) published a "decalogue" summarizing the essential recommendations to follow when reporting on the pandemic. ${ }^{1}$ In short, those instructions amounted to the need to publish accurate and truthful information, avoid the use of sensationalist pictures and language, give publicity to available scientific evidence and use clear language that is accessible to the general public [2020]. Basically, the AECC asked that the media fulfill a public service function. In the context described so far, it is worth wondering if the abundant content on the COVID-19 pandemic has been useful to provide an answer to the communication needs that the scientific community pointed out.

The general objective of this research is to define the scientific community's perception of media reports on the coronavirus pandemic in Spain. This general objective is then divided into the following more specific objectives:

O1. Firstly, learn how often the Spanish scientific community used the media to find out about the evolution of the pandemic.

O2. Establish whether - in the opinion of Spanish scientists - there are differences in the way television networks, radio stations, newspapers and digital media reported on the pandemic or, on the contrary, they all reported the news in the same form.

O3. Check how the Spanish scientific community evaluates the media's journalistic coverage according to parameters such as rigor, realism, sensationalism and public utility, concepts that are in line with the recommendations by entities such as the AECC.

O4. Establish what themes were predominant in the media and what functions they fulfilled in reporting on the pandemic, and what they should have been from the point of view of the scientific community.

\footnotetext{
${ }^{1}$ The decalogue can be found in its entirety at the following link: https:/ / www.aecomunicacioncientifica.org/consejos-para-informar-sobre-el-coronavirus/.
} 
To achieve the objectives set out above, the research was carried out through a survey, a proven methodology that is especially suitable when working with large amounts of data [de Leeuw, Hox and Dillman, 2008; Foddy, 1993; Ferrando, Ibáñez and Alvira, 2000; Ghiglione and Matalon, 2004]. A survey is defined as a research technique based on two substantial parameters: the use of structured questionnaires as a basic element to obtain information and the use of samples that are representative of a given population [Alvira Martín, 2011, p. 7].

In the case of the present study, the questionnaire prepared - which is presented below - was sent to all the scientific societies of health professionals listed by the Ministry of Health of the Government of Spain, ${ }^{2}$ regardless of their field of expertise. In turn, the organizations submitted the questionnaire to their members via email. It was decided to include all scientific societies of health professionals in the research because the coronavirus disease can have consequences in practically all areas of health and because, in one way or another, the virus has unquestionably affected health professionals in the performance of their public healthcare work. This is demonstrated by the suspension of surgical procedures of a different nature [Valdés, 2020], the forced transfers of all types of professionals to ad hoc hospitals built to deal with the consequences of the pandemic [Plaza Casares, 2020], the transfers to and the reforms and expansions of Primary Care departments [Congostrina, 2020], the changes in the routine of IC unit operators [Minocri, 2020] as well as geriatricians and gerontologists [Jurado, 2020], the delayed diagnoses of diseases such as cancer [Infobae, 2020] and, ultimately, the adaptation of all health professionals to a new healthcare reality, as mentioned above [Heraldo de Aragón, 2020; Simón, 2020].

The study was conducted between July 22 and October 15 for various reasons: firstly, it was sensible to delay the start of the investigation until well into the summer so we could be sure that the so-called first wave of the pandemic was behind us and, therefore, we could obtain an exhaustive view of the journalistic coverage in the media: in short, in this way we could ensure an interesting retrospective. On the other hand, we decided to conclude the survey on October 15 based on two criteria: it guaranteed us a sufficient period of time to obtain the desired number of responses and, at the same time, we made sure that the research did not lose relevance.

It was decided that the survey should be disseminated via email as it was the only feasible way to carry out the research. Indeed, the group of respondents consisted of various members of scientific societies of health professionals living all around Spain and abroad. The decision to carry out the survey via the Internet allowed for faster collection of information, lower research costs [Díaz de Rada, 2012, p. 212] and prevented any influence from interviewers [López-Roldán and Fachelli, 2015, p. 15].

In total, we collected 818 questionnaires answered by members of the scientific societies of health professionals approved by the Ministry of Health. Among the respondents, $90.1 \%$ said that they currently practice a health science profession,

\footnotetext{
${ }^{2} \mathrm{~A}$ complete list of the scientific societies of health professionals - this is the exact nomenclature used by the Government of Spain to refer to them - recognized by the Spanish Ministry of Health can be found at the following link: https://www.mscbs.gob.es/profesionales/socCientificas/especialidades.htm.
} 
Table 1. Survey description.

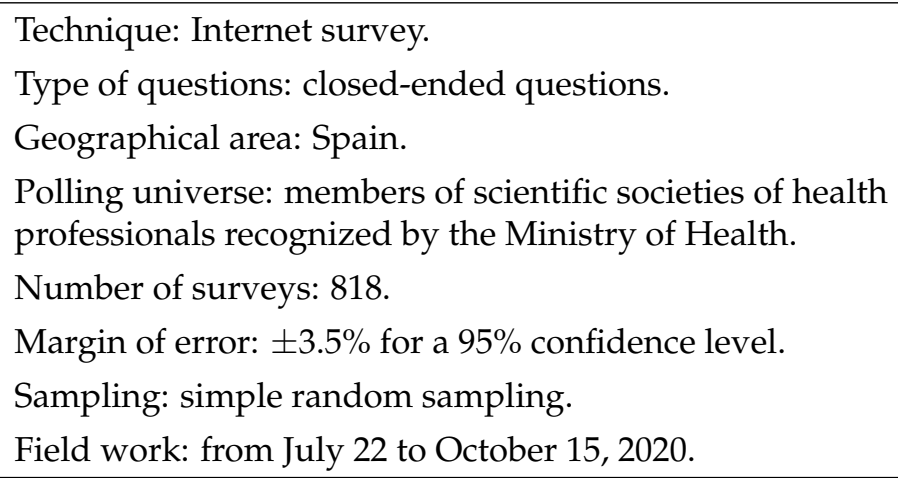

while $9.9 \%$ said that they currently do not. $62.4 \%$ of the total respondents said they identify with the female gender, $36.6 \%$ identify as male and $1 \%$ preferred not to answer this question. In terms of age groups, $6.8 \%$ of the questionnaires submitted were from people under 30 years of age, $45.5 \%$ from people between 30 and 50 years old, $45.4 \%$ from people between 51 and 70 years old, and $2.3 \%$ from people over 70 years of age.

Similarly, submissions were received from all the Spanish Autonomous Communities, ${ }^{3}$ distributed as follows: Madrid, 22.7\%; Catalonia, 12.8\%; Andalusia, 9.9\%; Castilla y León, 7.5\%; Aragon, 7.1\%; Valencian Community, 7.1\%; Basque Country, 4.9\%; Galicia, 4.6\%; Canary Islands, 3.9\%; Navarra, 3.6\%; Castilla-La Mancha, 3.1\%; Asturias, 2.9\%; Balearic Islands, 2.3\%; Extremadura, 2.1\%; Murcia, 2.1\%; Cantabria, 1.7\%; and La Rioja, 1.7\%.

In addition, in terms of medical specialties, it should be noted that the submissions were sent by professionals specializing in a wide range of areas, including Geriatrics and Gerontology (17.9\%), Hematology (11\%), Immunology (10.5\%), Pharmacy (12.6\%), Nursing (6.1\%), Pulmonology (3.9\%), Genetics (3.4\%), General Medicine (2.9\%), Emergency Medicine (2.7\%), Pediatrics (2.7\%), Medical Documentation (2.6\%), Bioethics (1.3\%), Intensive Care Medicine (1.2\%), Public Health $(1.2 \%)$, Epidemiology (1.1\%), Palliative care $(0.6 \%)$, Virology $(0.5 \%)$ and Others $(17.8 \%)$.

The questionnaire drafted by the researchers serves a dual purpose. On the one hand, it aims to describe the general characteristics of the scientific community's perception of the Spanish media coverage of the COVID-19 pandemic (descriptive purpose). On the other hand, its findings make it possible to establish causal connections between the variables examined [López Romo, 1998, p. 38] (causal purpose). Consequently, the questions ${ }^{4}$ listed in Table 2 were formulated to achieve such dual purpose:

\footnotetext{
${ }^{3}$ In this phase the researchers did not set the goal of learning whether there are differences in the perceptions of scientists from different Autonomous Communities or from different scientific societies, so the sample did not have to be stratified.

${ }^{4}$ Although they were part of the questionnaire, the questions and answer choices related to the gender, age, location and reference scientific society of the respondents were not included in the table. These aspects were useful to record the respondent profiling information as described above.
} 
Table 2. Survey questionnaire.

\begin{tabular}{|c|c|}
\hline Questions & Answer choices \\
\hline $\begin{array}{l}\text { Have you used Spanish media to learn about } \\
\text { the evolution of the COVID-19 pandemic? }\end{array}$ & $\begin{array}{l}\text { Yes, every day or virtually every day. } \\
\text { Yes, but intermittently. } \\
\text { Yes, but only on specific occasions. } \\
\text { No, I haven't followed the media. }\end{array}$ \\
\hline $\begin{array}{l}\text { How do you rate, in general, the media } \\
\text { coverage of the COVID-19 pandemic in Spain? }\end{array}$ & $\begin{array}{l}\text { Very good, basically perfect. } \\
\text { Good, but with specific errors. } \\
\text { Average, alternating instances of mistakes and } \\
\text { correct reports. } \\
\text { Bad, with relevant flaws in its treatment. } \\
\text { Very bad, with serious errors. }\end{array}$ \\
\hline $\begin{array}{l}\text { Have you watched television networks to learn } \\
\text { about the evolution of the pandemic? }\end{array}$ & $\begin{array}{l}\text { Yes, I have } \\
\text { No, I haven't }\end{array}$ \\
\hline $\begin{array}{l}\text { If you answered yes to the previous question, } \\
\text { how do you evaluate, as a whole and } \\
\text { specifically, the news coverage of the pandemic } \\
\text { in Spain by Spanish television channels? }\end{array}$ & $\begin{array}{l}\text { Very good, basically perfect. } \\
\text { Good, but with specific errors. } \\
\text { Average, alternating instances of mistakes and } \\
\text { correct reports. } \\
\text { Bad, with relevant flaws in its treatment. } \\
\text { Very bad, with serious errors. }\end{array}$ \\
\hline $\begin{array}{l}\text { Have you listened to radio stations to learn } \\
\text { about the evolution of the pandemic? }\end{array}$ & $\begin{array}{l}\text { Yes, I have } \\
\text { No, I haven't }\end{array}$ \\
\hline $\begin{array}{l}\text { If you answered yes to the previous question, } \\
\text { how do you evaluate, as a whole and } \\
\text { specifically, the news coverage of the pandemic } \\
\text { in Spain by Spanish radio stations? }\end{array}$ & $\begin{array}{l}\text { Very good, basically perfect. } \\
\text { Good, but with specific errors. } \\
\text { Average, alternating instances of mistakes and } \\
\text { correct reports. } \\
\text { Bad, with relevant flaws in its treatment. } \\
\text { Very bad, with serious errors. }\end{array}$ \\
\hline $\begin{array}{l}\text { Have you read print media to learn about the } \\
\text { evolution of the pandemic? }\end{array}$ & $\begin{array}{l}\text { Yes, I have } \\
\text { No, I haven't }\end{array}$ \\
\hline $\begin{array}{l}\text { If you answered yes to the previous question, } \\
\text { how do you evaluate, as a whole and } \\
\text { specifically, the news coverage of the pandemic } \\
\text { in Spain by Spanish print media? }\end{array}$ & $\begin{array}{l}\text { Very good, basically perfect. } \\
\text { Good, but with specific errors. } \\
\text { Average, alternating instances of mistakes and } \\
\text { correct reports. } \\
\text { Bad, with relevant flaws in its treatment. } \\
\text { Very bad, with serious errors. }\end{array}$ \\
\hline $\begin{array}{l}\text { Have you used online news outlets to learn } \\
\text { about the evolution of the pandemic? }\end{array}$ & $\begin{array}{l}\text { Yes, I have } \\
\text { No, I haven't }\end{array}$ \\
\hline $\begin{array}{l}\text { If you answered yes to the previous question, } \\
\text { how do you evaluate, as a whole and } \\
\text { specifically, the news coverage of the pandemic } \\
\text { in Spain by Spanish online news outlets? }\end{array}$ & $\begin{array}{l}\text { Very good, basically perfect. } \\
\text { Good, but with specific errors. } \\
\text { Average, alternating instances of mistakes and } \\
\text { correct reports. } \\
\text { Bad, with relevant flaws in its treatment. } \\
\text { Very bad, with serious errors. }\end{array}$ \\
\hline $\begin{array}{l}\text { In your opinion, which subject has been more } \\
\text { predominant in the media when reporting on } \\
\text { the pandemic? }\end{array}$ & $\begin{array}{l}\text { The political management of the pandemic. } \\
\text { The health management of the pandemic. } \\
\text { The disease itself. } \\
\text { Economic consequences of the pandemic. } \\
\text { Social consequences of the pandemic. } \\
\text { Other themes. }\end{array}$ \\
\hline
\end{tabular}

Continued on the next page. 
Table 2. Continued from the previous page.

\begin{tabular}{|c|c|}
\hline Questions & Answer choices \\
\hline $\begin{array}{l}\text { In your opinion, which subject should have } \\
\text { been more predominant in the media when } \\
\text { reporting on the pandemic? }\end{array}$ & $\begin{array}{l}\text { The political management of the pandemic. } \\
\text { The health management of the pandemic. } \\
\text { The disease itself. } \\
\text { Economic consequences of the pandemic. } \\
\text { Social consequences of the pandemic. } \\
\text { Other themes. }\end{array}$ \\
\hline $\begin{array}{l}\text { In your opinion, which function have the } \\
\text { Spanish media served during the pandemic? }\end{array}$ & $\begin{array}{l}\text { Informative. } \\
\text { Entertainment. } \\
\text { Social mobilization. } \\
\text { Keeping the status quo. } \\
\text { Controlling political powers. } \\
\text { Other functions. }\end{array}$ \\
\hline $\begin{array}{l}\text { In your opinion, which function should the } \\
\text { Spanish media have served during the } \\
\text { pandemic? }\end{array}$ & $\begin{array}{l}\text { Informative. } \\
\text { Entertainment. } \\
\text { Social mobilization. } \\
\text { Keeping the status quo. } \\
\text { Controlling political powers. } \\
\text { Other functions. }\end{array}$ \\
\hline $\begin{array}{l}\text { Rate the following questions on a scale of } 1 \text { to } 5 \\
\text { according to the specifications: } \\
\text { Do you think that media outlets have generally } \\
\text { covered the pandemic with rigor? } \\
\text { Do you think that media outlets have generally } \\
\text { covered the pandemic with realism? } \\
\text { Do you think that media outlets have generally } \\
\text { covered the pandemic with a sensationalistic } \\
\text { tone? } \\
\text { Do you think that media outlets have generally } \\
\text { covered the pandemic in a pedagogical way? } \\
\text { Do you think that media outlets have generally } \\
\text { covered the most relevant aspects of the } \\
\text { pandemic? }\end{array}$ & $\begin{array}{l}\text { 1. Never or virtually never. } \\
\text { 2. On specific occasions. } \\
\text { 3. Intermittently. } \\
\text { 4. Very often. } \\
\text { 5. Always or virtually always. }\end{array}$ \\
\hline
\end{tabular}

\subsection{Assessment of journalistic coverage in general and by type of medium}

As shown in Figure 1, according to the research findings, the majority of the surveyed members of the scientific societies of health professionals used the media to learn about the evolution of the pandemic very frequently - virtually every day: indeed, $55.7 \%$ of respondents selected this option. In addition, $29.2 \%$ used the media frequently yet intermittently, that is, not every single day.

Such figures reveal the substantial interest of scientists in the information released in the media. Only $2.2 \%$ of respondents said that they did not follow the media during the pandemic, while $12.8 \%$ said that they used the media at specific times. The high media use rate during the pandemic by health professionals is not an exception as it is in line with the increase in media consumption that occurred since March 2020 and during lockdown in particular. Among other things, radio reported over 20 million weekly listeners, while the number of newspaper and magazine readers reported an increase [Asociación para la Investigación de Medios de Comunicación, 2020]. 


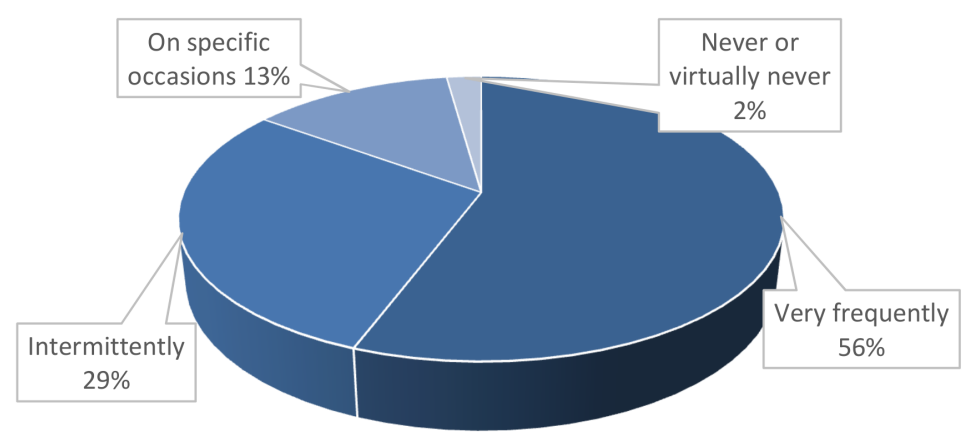

- Very frequently - Intermittently - On specific occasions - Never or virtually never

Figure 1. Scientists' media use rate.

$30.5 \%$ of health professionals who looked for information about the evolution of the pandemic through the media approve of the role it played, and consider it as "good" or "very good". However, according to the research findings shown in Figure 2,39.2\% think that the media alternated instances of mistakes and correct reports in their coverage, hence they describe the role played by the media as "average". In addition, among those who think that journalistic coverage can evidently be improved, we found that $17 \%$ of respondents rate it as "bad" - with relevant flaws in the journalistic treatment - and 12\% rate it as "very bad" - with very serious recurrent mistakes -

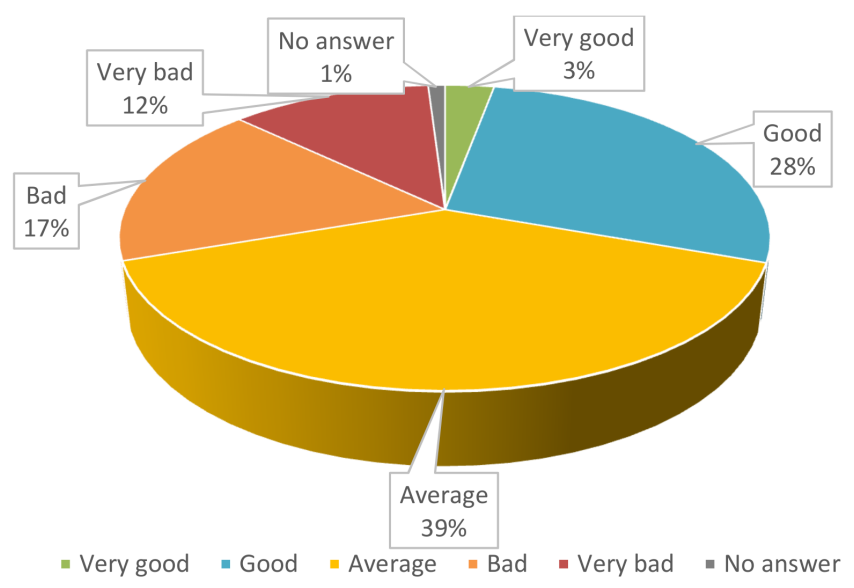

Figure 2. The scientist's global evaluation of the pandemic journalistic coverage.

As illustrated below, those mistakes involve issues with information selection and the thematic approach, media focus and more specific aspects such as the accuracy, realism or sensationalism of the pieces of news.

The evaluation of Spanish health professionals differs depending on the type of medium. Similarly, their consumption of each type of medium also varies. In this respect, the hegemony of digital media and television stands out: $92.4 \%$ and $92.1 \%$ of the respondents said that they kept themselves informed about the pandemic respectively through one or the other medium. Although still considerable, the print media $(76.8 \%)$ and the radio $(71.5 \%)$ played a secondary role as sources of information about the pandemic. 


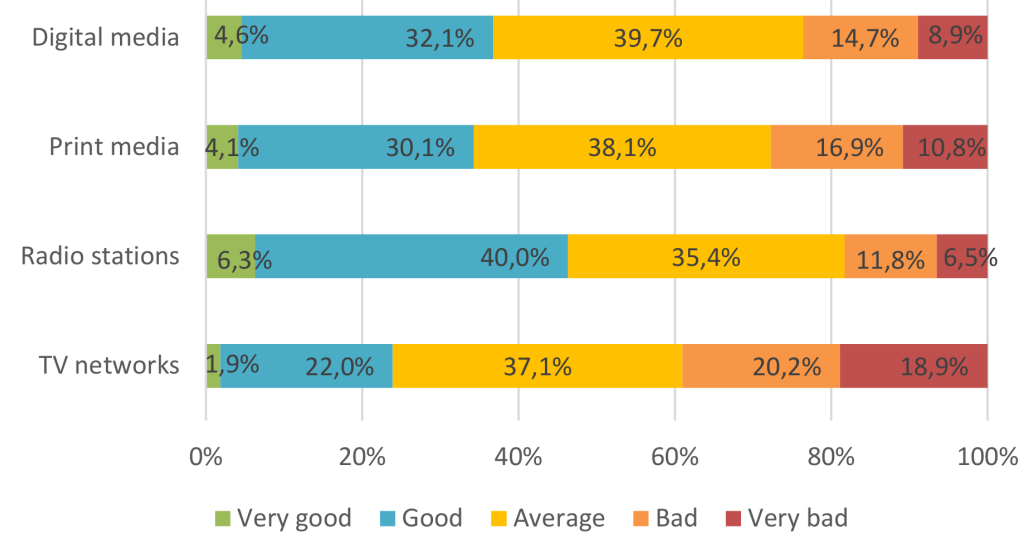

Figure 3. Evaluation of the pandemic journalistic coverage by type of medium.

Regardless of the consumption level, Figure 3 summarizes the health professionals' specific perception of the pandemic journalistic coverage by type of medium. Radio stations are those that obtained the best evaluation, as $46.3 \%$ of the respondents consider their news production as "good" or "very good". The second best-rated coverage refers to digital media: $36.7 \%$ define it as "good" or "very good", a figure similar to print media (34.2\%) but much higher than television networks $(23.9 \%)$.

If we establish a link between the two previous findings, we can observe that radio is the medium that was used the least to follow the pandemic. However, it is the medium that was best evaluated by the scientific community. On the other hand, the evolution of the pandemic was commonly followed through television, but its news production appears to be the most criticized. The positive evaluations of radio amount to twice as many as those of television, but paradoxically radio consumption is 20 points lower. In relation to negative evaluations, we found an opposite scenario: $39.1 \%$ think that TV channels did a "bad" or "very bad" job in reporting on the pandemic. It is twice as much as the share of respondents that said the same of radio stations $(18.3 \%)$.

The positive evaluation of the work of radio among scientists reaffirms Rodero's idea that "radio is the medium that best addresses the crisis" [2020, p. 10]. In her recent research on listening habits, consumption and perception of radio listeners during lockdown, the author links the success of radio with its informative nature, high credibility and closeness to the audience.

The question of why - despite the findings above - television consumption still predominates within the scientific community is probably explained with the penetration rate of television in Spain, which is $85.4 \%$, a figure that is much higher than radio $(56.9 \%)$, newspapers $(21.7 \%)$ or magazines $(29.4 \%)$ [Orús, 2020 ].

\subsection{Evaluation of the content and subjects of the news pieces}

The research revealed that there are notable differences between the subjects that health professionals identified as predominant in the media during the pandemic months and those that they expected to be the main focus. As can be seen in Figure 4 , the participants in the study pointed to what we could practically define 

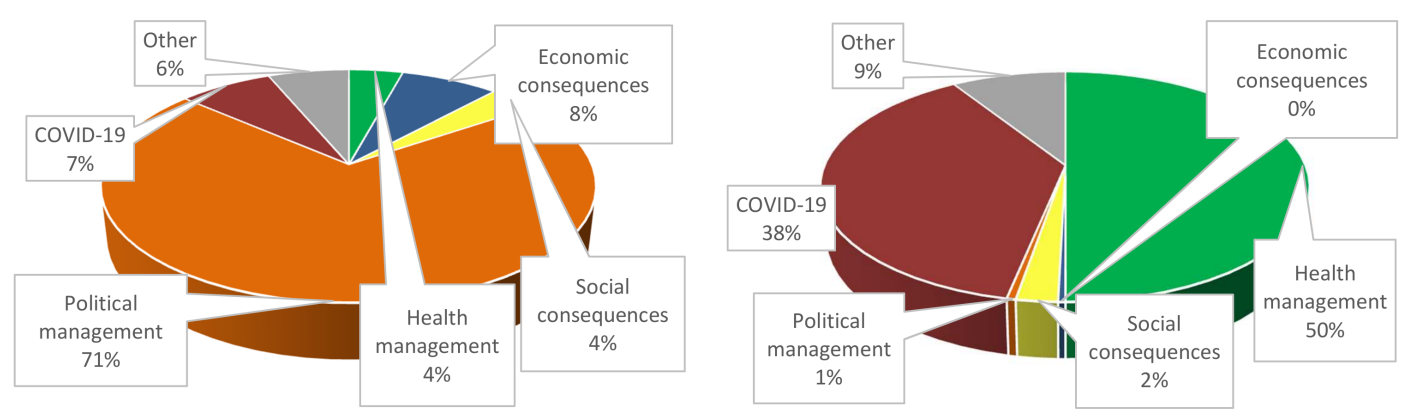

Figure 4. Main subjects in news pieces (left) compared to the expected main subjects (right) according to the scientists interviewed.

as the thematic monopoly of political management in media reports during the pandemic. Indeed, $70.9 \%$ of the respondents think that it was the theme covered the most, well ahead of health management issues (4\%), the coronavirus disease itself $(7 \%)$ or the economic $(8 \%)$ and social $(4 \%)$ repercussions.

The perception of health professionals is in contrast with their own idea of what should have been the main focus in the news: $50 \%$ think that health management should have been the most featured subject in the media. Consistently with this opinion, $37.8 \%$ of the respondents mentioned the disease itself and its consequences. Conversely, the respondents attach substantially less importance to the coverage of other issues, such as the political management $(0.5 \%)$ and the economic $(0.4 \%)$ and social $(2.3 \%)$ repercussions of the pandemic.

Essentially, the Spanish scientific community pointed out that there was an excess of politics in the media and that, in a context of a pandemic, what should be really relevant is the healthcare management of the disease and the features of the disease itself.

The finding above leads us to investigate the role played by the media during the pandemic. The research on the professional roles of journalists has a long tradition [Cohen, 1963; Janowitz, 1975]. Our reference will be the categorization by Berganza, Lavín and Piñeiro-Naval [2017], which is recent and already applied to the Spanish context. These authors identified six categories of journalistic roles: guard dog - which in our case will be understood as 'political control' -, speaker of the citizens, trainer of the audience - which in our case is closely related to training, mobilization and social awareness - , supporter of the status quo, entertainer of the general public and disseminator of objective information.

In this sense, the study revealed once again that there are profound differences between the reality perceived by health professionals and the scenario that they expected (see Figure 5). Indeed, $28.5 \%$ of the scientists interviewed think that the role the media played in the pandemic was to control political powers, while $27.1 \%$ think that the media played an informative role. However, according to $71 \%$ of the respondents, such informative role should have been the main focus in the journalistic coverage of the pandemic. In fact, the share of scientists who believe that in the context of a health crisis such as the current one the media should have given priority to its informative role is three times as large as the share of those who think that it was actually the case. 

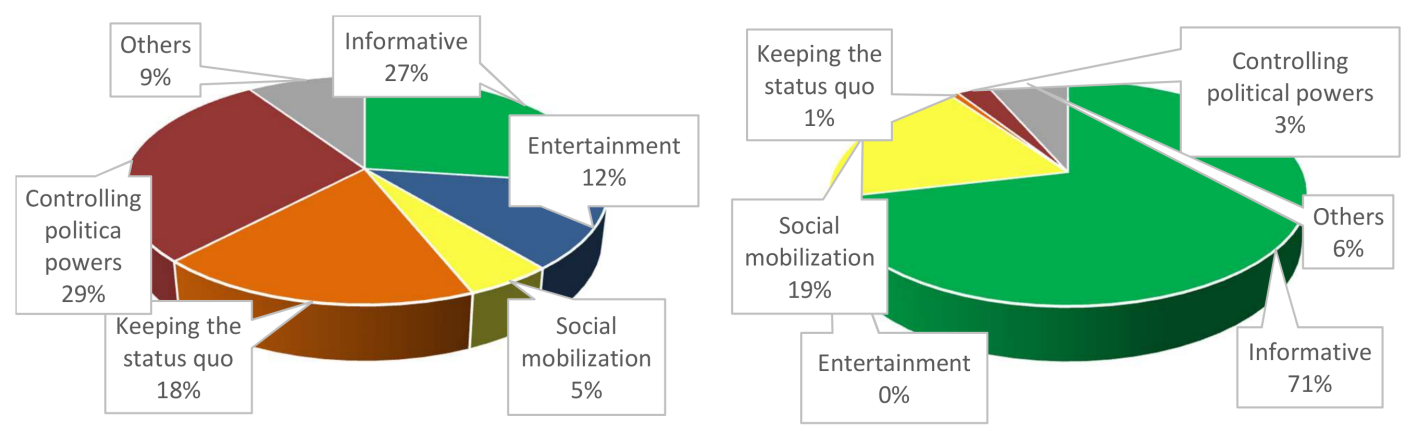

Figure 5. Role played by the media in the pandemic (left) versus main expected role (right) according to the scientists interviewed.

On the other hand, quite interestingly, only $5 \%$ of the scientists interviewed think that the media fulfilled a society mobilizer function, but a lot more (19\%) believe that such function should have been more prominent in journalistic coverage. In this particular case, the media should have played that role to make the public aware of the need to comply with the rules to avoid infections as the scientists themselves instructed.

In addition, according to the respondents the entertainment function should have totally disappeared from the media during pandemic. At the same time, they think that entertainment inspired news pieces in $12 \%$ of the cases.

Asked about some of the most prominent features of the pandemic media coverage (see Figure 6), it should be noted that $41 \%$ of the respondents said they perceived an excess of sensationalism. Another $34.2 \%$ of the scientists participating in the study found that a sensationalist tone was present "quite a lot" in the media. In total, three out of four experts think that sensationalism prevailed in journalistic information over other parameters, while only $3.1 \%$ of the respondents think that the media were not sensationalistic at all, and 7\% think that sensationalism was "only scarcely present".

The analysis by health professionals above should ultimately be interpreted as negative criticism, a view that is reiterated for the other four aspects reviewed in

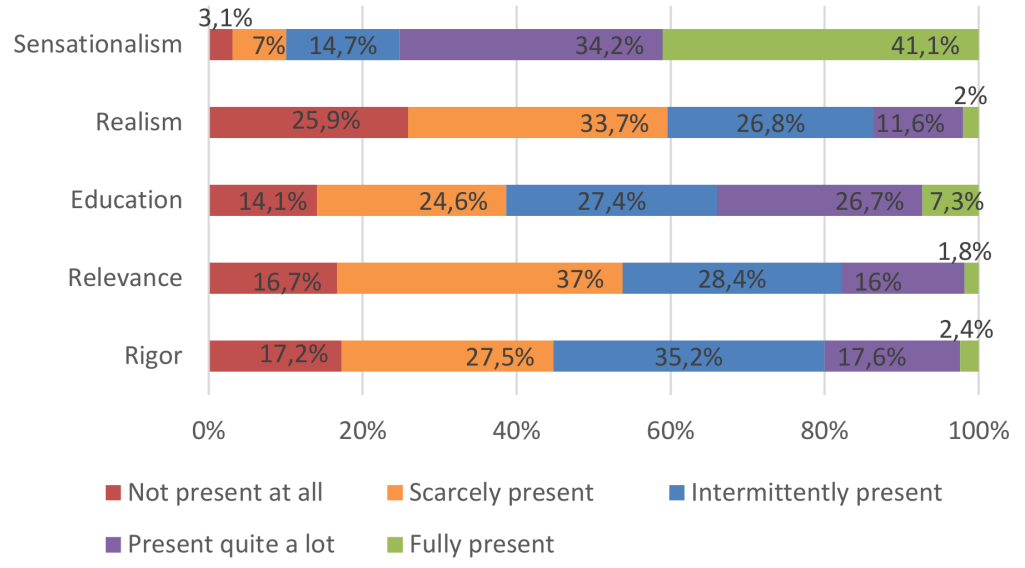

Figure 6. Evaluation of the presence of the main media coverage features according to the scientific community. 
the survey: realism in covering the pandemic, rigor of the information, relevance of the approaches and realism of journalistic attitudes. More than half of the scientists surveyed (59.6\%) said that the news pieces appeared in the Spanish media were not realistic, while $53.7 \%$ said that they were not focused on the truly relevant aspects. In addition, $17.2 \%$ thought that journalists were not rigorous "at all", while $27.5 \%$ said that the information was "scarcely" rigorous.

Finally, the news coverage aspect that the scientific sector interviewees pointed out as the most positive is that the media helped people understand what the coronavirus is and what the consequences of the pandemic are for citizens. In particular, $7.3 \%$ think that in this perspective the media "fully" performed this function, while $26.7 \%$ think that it did so "quite a lot". The positive assessment of this last aspect is very much in line with the health professionals' opinion seen above that the media should fulfill an informative role and act to mobilize, train and raise awareness among the citizens.

Discussion and conclusions
The coronavirus pandemic news coverage aroused notable interest among the members of the scientific community, the majority of whom followed the evolution of the health crisis through the media on a daily basis (O1). In any case, such interest varied depending on the type of media. For example, digital media and television are those that were most used by scientists to find information, far ahead of print media and radio. Other recent studies on media consumption during a pandemic also confirmed the primacy of television over other media, although such studies significantly reduce the impact of radio and print media [Montaña Blasco, Ollé Castellà and Lavilla Raso, 2020].

There is not any statistical correlation between higher consumption of a certain media category and a higher evaluation of its pandemic coverage. In other words, the most consumed types of media are not so because the respondents hold them in higher regard. In fact, we could actually say the opposite: radio is the least consumed medium, however it is the best valued, while television is the second most consumed medium, but it is the one with the worst evaluations (O2).

In this respect, as García-Santamaría, Pérez-Serrano and Rodríguez Pallarés concluded, while it is true that the pandemic enhanced the value of "the information resources of free-to-air television platforms, to the obvious detriment of the press (digital natives included) and even radio" [2020, p. 15] and that such TV broadcasters enlarged their audiences, the Spanish scientific community maintains that the contribution of television channels was not even remotely the most successful. Thus, this apparent contradiction of the consumption-credibility pair pushes us to continue reflecting on issues such as those raised by Tsfati and Cappella [2005] about why we consume media that we do not deem as credible. A factor that could explain this fact is that traditionally the media penetration rate has hardly changed. In fact, statistics show that television has never dropped from its $85 \%$ penetration rate since 1997 , while radio and newspapers have never gone beyond $61 \%$ and $42 \%$ respectively [Nafría, 2018].

On the other hand, the findings of the research allow us to conclude that the members of the scientific community think that — in general terms - rigor and realism have been lacking in the media and that there has been an excess of 
sensationalism (O3). In other words, none of the guidelines set by the Asociación Española de Comunicación Científica [2020], among others, which were presented at the beginning of this paper, was met. In addition, the lower the perceived realism, rigor and relevance of the news pieces, the more the perception of sensationalism increases.

The lack of rigor reported by the Spanish scientific community translates into practical issues which a few recent research projects have already focused on. For example, Andreu-Sánchez and Martín-Pascual found that, since the beginning of the pandemic, "the media have used more fake images of the coronavirus - often from paid image stocks or repositories - than genuine ones" [2020, p. 1] and concluded that "this lack of accuracy in the pictures of the coronavirus is not only due to a metaphorical use of pictures" [2020, p. 9].

The sensationalism detected in media coverage during this pandemic is not something new, since it was already evident during previous health crises. As Costa-Sánchez and López-García recalled: "Previous research on the press coverage of the swine flu pandemic revealed high alarmism. In addition, it was pointed out that the alarmism was accompanied by a certain degree of sensationalism as personal and clinical data of some people affected by the disease was disseminated [...]. In addition, the media did not always respect the confidentiality rules of the patients' medical records and their right to privacy" [2020, p. 7].

Sensationalism was already a main feature in the news coverage of the Ebola crisis [Monjas Eleta and Gil-Torres, 2017]. For example, it was evident in the treatment of images and the use of information sources. This finding also coincides with the opinion of Villena and Caballero: in their study - specifically conducted on the first channel of Spanish public television (TVE) - they identified sensationalism as the concept that was most frequently reiterated by the experts participating in a focus group on the current pandemic that included communication experts, physicians, journalists and university professors [2020, p. 119].

Finally, in relation to the subjects that were predominant in the media $(\mathrm{O} 4)$, there was a general perception of a sort of "monopoly" of politics to the detriment of other issues such as healthcare management and the COVID-19 disease, which are the aspects that scientists conversely deemed as the most important. This is related to the role that the media play and were expected to played. Whereas the Asociacion Española de Comunicación Cientifica recommended that the media should fulfill a public service function, the scientists interviewed think that the media have mainly fulfilled a function that is more related to political control and the maintenance of the status quo.

However, without disregarding the difficulties the media encounters in carrying out its informative work in this context, it is evident that the relations between the media - and consequently journalists - and healthcare professionals require a reform. It is necessary to strengthen the relations between legislators, journalists and health professionals [Bernadas and Ilagan, 2020] because it would help to identify possible errors in the dissemination of information and combat fake news [Larsson et al., 2003].

However, through this research it was possible to approach the perception that the members of the scientific community have of the role played by the media in this 
pandemic, although with some limitations. One of them is that it would be interesting to compare the data collected with further data on the perception that journalists and/or media audiences have, among others. Similarly, this study paves the way to further developments: a more generalized analysis of media coverage in health crisis situations; the development of a good practices handbook that could be useful on future occasions; the study of the role that science played in the media coverage of COVID-19; the study of the relations that were established between journalists and scientists.

Translated by Massimo Caregnato

\section{References}

Adhanom, T. (2020). 'Munich security conference'. World Health Organization. URL: h ttps://www.who.int/dg/speeches/detail/munich-security-conference.

Alvira Martín, F. (2011). La encuesta: una perspectiva general metodológica. Vol. 35. Cuadernos Metodológicos. Madrid, Spain: Centro de Investigaciones Sociológicas.

Andreu-Sánchez, C. and Martín-Pascual, M.-Á. (2020). 'Fake images of the SARS-CoV-2 coronavirus in the communication of information at the beginning of the first Covid-19 pandemic'. El Profesional de la Información 29 (3), e290309. https://doi.org/10.3145/epi.2020.may.09.

Arteaga-Livias, F. K. and Rodriguez-Morales, A. J. (2020). 'La comunicación científica y el acceso abierto en la contención de enfermedades: el caso del Coronavirus novel 2019 (2019-nCoV)'. Revista Peruana de Investigación en Salud 4 (1), pp. 7-8. https://doi.org/10.35839/repis.4.1.613.

Asociación Española de Comunicación Científica (2020). ‘Consejos para informar sobre el nuevo coronavirus'. AECC. URL: https://www aecomunicacioncientif ica.org/consejos-para-informar-sobre-el-coronavirus/ (visited on 10th September 2020).

Asociación para la Investigación de Medios de Comunicación (2020). ‘Cuaderno de Bitácora. Estudio de medios en la España confinada'. AIMC.

URL: https://www . aimc.es/blog/aumenta-la-lectura-prensa-revistas-pap el-estado-alarma-los-internautas/ (visited on 17th December 2020).

Berganza, R., Lavín, E. and Piñeiro-Naval, V. (2017). 'La percepción de los periodistas españoles acerca de sus roles profesionales'. Comunicar 51 (25), pp. 83-92. https://doi.org/10.3916/C51-2017-08.

Bernadas, J. M. A. C. and Ilagan, K. (2020). 'Journalism, public health, and COVID-19: some preliminary insights from the Philippines'. Media International Australia 177 (1), pp. 132-138. https://doi .org/10.1177/1329878X20953854.

Cohen, B. C. (1963). The press and foreign policy. Princeton Legacy Library. Princeton, NJ, U.S.A.: Princeton University Press.

Congostrina, A. L. (2020). 'La crisis sanitaria obliga a trasladar y ampliar cuatro ambulatorios de Barcelona'. El País. URL: https://elpais .com/espana/catalun ya/2020-12-21/la-crisis-sanitaria-obliga-a-trasladar-y-ampliar-cuat ro-ambulatorios-de-barcelona. html (visited on 21st December 2020).

Costa-Sánchez, C. and López-García, X. (2020). ‘Comunicación y crisis del coronavirus en España. Primeras lecciones'. El Profesional de la Información 29 (3), e290304. https://doi.org/10.3145/epi.2020.may.04.

de Leeuw, E. D., Hox, J. and Dillman, D., eds. (2008). International handbook of survey methodology. New York, NY, U.S.A.: Lawrence Erlbaum Associates. 
Depoux, A., Martin, S., Karafillakis, E., Preet, R., Wilder-Smith, A. and Larson, H. (2020). 'The pandemic of social media panic travels faster than the COVID-19 outbreak'. Journal of Travel Medicine 27 (3), taaa031.

https://doi.org/10.1093/jtm/taaa031.

Díaz de Rada, V. (2012). 'Ventajas e inconvenientes de la encuesta por Internet'. Papers: Revista de Sociología 97 (1), pp. 193-223.

URL: https://www.raco . cat/index.php/Papers/article/view/248512.

Ferrando, M. G., Ibáñez, J. and Alvira, F., eds. (2000). El análisis de la realidad social. Métodos y técnicas de investigación. Madrid, Spain: Alianza Editorial.

Foddy, W. (1993). Constructing questions for interviews and questionnaires. Theory and practice in social research. Cambridge, U.K.: Cambridge University Press.

García-Santamaría, J.-V., Pérez-Serrano, M.-J. and Rodríguez-Pallares, M. (2020). 'Portavoces oficiales y estrategia audiovisual en la crisis de la Covid-19 en España'. El Profesional de la Información 29 (5), e290513. https://doi.org/10.3145/epi.2020.sep.13.

Garrett, L. (2020). 'COVID-19: the medium is the message'. The Lancet 395 (10228), pp. 942-943. https://doi.org/10.1016/S0140-6736(20)30600-0.

Ghiglione, R. and Matalon, B. (2004). Les enquêtes sociologiques. Théories et pratique. 6th ed. Paris, France: Armand Colin.

Heraldo de Aragón (2020). 'Si los hospitales se colapsan, no vamos a poder atender a más pacientes de coronavirus, ni por infartos o accidentes'. Heraldo de Aragón. URL: https://www .heraldo.es/noticias/aragon/2020/11/19/concienciacio n-sanitarios-aragoneses-coronavirus-1406032.html (visited on 7th December 2020).

Hua, J. and Shaw, R. (2020). 'Corona Virus (COVID-19) "infodemic" and emerging issues through a data lens: the case of China'. International Journal of Environmental Research and Public Health 17 (7), 2309. https://doi.org/10.3390/ijerph17072309.

Infobae (2020). 'Daño colateral de la pandemia: los progresos importantes contra el cáncer se retrasarían casi un año y medio'. Infobae.

URL: https://www .infobae.com/america/ciencia-america/2020/12/06/dano -colateral-de-la-pandemia-los-progresos-importantes-contra-el-cance r-se-retrasarian-casi-un-ano-y-medio/ (visited on 7th December 2020).

Janowitz, M. (1975). 'Professional models in journalism: the gatekeeper and the advocate'. Journalism \& Mass Communication Quarterly 52 (4), pp. 618-626. https://doi.org/10.1177/107769907505200402.

Jurado, M. (2020). 'El coronavirus pone en evidencia el déficit de geriatras en España'. 65 y Más. URL: https://www .65ymas . com/sociedad/coronavirus-pon e-en-evidencia-deficit-geriatras-en-espana_21040_102.html (visited on 19th December 2020).

Larsson, A., Oxman, A. D., Carling, C. and Herrin, J. (2003). 'Medical messages in the media - barriers and solutions to improving medical journalism'. Health Expectations 6 (4), pp. 323-331. https://doi.org/10.1046/j.1369-7625.2003.00228.x.

López Romo, H. (1998). 'La metodología de encuesta'. In: Técnicas de investigación en sociedad, cultura y comunicación. Ed. by L. J. Galindo Cáceres. Mexico: Addison Wesley Longman.

López-Roldán, P. and Fachelli, S. (2015). Metodología de la investigación social cuantitativa. Bellaterra, Spain: Universitat Autònoma de Barcelona. URL: https://ddd.uab.cat/record/129382. 
Minocri, M. (2020). 'La batalla diaria de una médico intensivista, en imágenes'. El País. URL: https://elpais.com/elpais/2020/12/07/album/1607349875_379 303. html (visited on 20th December 2020).

Monjas Eleta, M. and Gil-Torres, A. (2017). 'Comunicación institucional y tratamiento periodístico de la crisis del ébola en España entre el 6 y el 8 de octubre de 2014'. Revista de Comunicación 16 (1), pp. 97-121.

URL: https://revistadecomunicacion.com/article/view/1009.

Montaña Blasco, M., Ollé Castellà, C. and Lavilla Raso, M. (2020). 'Impacto de la pandemia de Covid-19 en el consumo de medios en España'. Revista Latina de Comunicación Social 78, pp. 155-167. https: //doi .org/10.4185/RLCS-2020-1472.

Nafría, I. (2018). 'Así ha evolucionado la penetración de los medios en España'. The New Barcelona Post. URL: https : / www . thenewbarcelonapost . com/asi-haevolucionado-la-penetracion-de-los-medios-en-espana/ (visited on 16th December 2020).

Ophir, Y. (2019). 'The effects of news coverage of epidemics on public support for and compliance with the CDC - An experimental study'. Journal of Health Communication 24 (5), pp. 547-558. https://doi.org/10.1080/10810730.2019.1632990.

Orús, A. (2020). ‘Porcentaje de individuos que utilizó los diferentes medios de comunicación en España en 2019'. Statista.

URL: https://es . statista.com/estadisticas/473262/penetracion-de-losmedios-de-comunicacion-en-espana-por-tipo-de-medio/ (visited on 16th December 2020).

Papa, V. and Maniou, T. A. (2020). 'Recurrent narratives around the COVID-19 crisis in social networks: a case study analysis on Facebook'. Trípodos 47 (2), pp. 11-27. URL: http://www. tripodos.com/index.php/Facultat_Comunicacio _Blanquerna/article/view/813/832.

Pérez-Dasilva, J.-A., Meso-Ayerdi, K. and Mendiguren-Galdospín, T. (2020). ‘Fake news y coronavirus: detección de los principales actores y tendencias a través del análisis de las conversaciones en Twitter'. El Profesional de la Información 29 (3), e290308. https://doi.org/10.3145/epi . 2020. may. 08.

Pieri, E. (2019). 'Media framing and the threat of global pandemics: the ebola crisis in U.K. media and policy response'. Sociological Research Online 24 (1), pp. 73-92. https://doi.org/10.1177/1360780418811966.

Plaza Casares, S. (2020). 'Más de una decena de protestas en hospitales contra el traslado forzoso hasta el Isabel Zendal'. El Salto.

URL: https://www.elsaltodiario.com/coronavirus/protestas-concentraci ones-contra-el-traslado-forzoso-isabel-zendal-ayuso (visited on 21st December 2020).

Qiu, W. and Chu, C. (2019). 'Clarification of the concept of risk communication and its role in public health crisis management in China'. Disaster Medicine and Public Health Preparedness 13 (5-6), pp. 834-836. https://doi.org/10.1017/dmp.2019.10.

Radu, R. (2020). 'Fighting the 'infodemic': legal responses to COVID-19 disinformation'. Social Media + Society 6 (3). https://doi.org/10.1177/2056305120948190.

Rodero, E. (2020). 'Radio: the medium that best copes in crises. Listening habits, consumption, and perception of radio listeners during the lockdown by the Covid-19'. El Profesional de la Información 29 (3), e290306.

https://doi.org/10.3145/epi.2020.may.06. 
Salaverría, R., Buslón, N., López-Pan, F., León, B., López-Goñi, I. and Erviti, M.-C. (2020). ‘Desinformación en tiempos de pandemia: tipología de los bulos sobre la Covid-19'. El Profesional de la Información 29 (3), e290315. https://doi.org/10.3145/epi.2020.may.15.

Simón, C. (2020). ‘La adaptación de los profesionales sanitarios a la COVID-19 ha garantizado la asistencia'. El Médico Interactivo.

URL: https://elmedicointeractivo.com/la-adaptacion-de-los-profesiona les-sanitarios-a-la-covid-19-ha-garantizado-la-asistencia/ (visited on 20th December 2020).

Tsfati, Y. and Cappella, J. N. (2005). 'Why do people watch news they do not trust? The need for cognition as a moderator in the association between news media skepticism and exposure'. Media Psychology 7 (3), pp. 251-271. https://doi.org/10.1207/S1532785XMEP0703_2.

Valdés, I. (2020). 'Los hospitales de Madrid dejaron de practicar 93.001 operaciones entre marzo y agosto'. El País. URL: https://elpais . com/espana/madrid/2020 -12-10/la-primera-ola-de-coronavirus-arraso-con-100000-operacionesen-los-hospitales-madrilenos.html (visited on 7th December 2020).

Villena-Alarcón, E. and Caballero-Galeote, L. (2020). 'COVID-19 media coverage on Spanish public TV'. Trípodos 47 (2), pp. 103-125.

https://doi.org/10.51698/tripodos.2020.47p103-126.

Author

Javier de Sola Pueyo. Ph.D. in Communication, MA in Marketing and Corporate Communication, BA in Journalism. Professor at the University of Zaragoza since 2016/2017 and Director of the 'Despierta Aragón' radio show on Aragón Radio, the radio of the autonomous region of Aragón. Member of the Research Group in Digital Communication and Information (GICID). He is currently focusing his investigation on the features and development of the radio as a medium and the way the various topical issues are treated in the media. E-mail: jdesola@unizar.es.

\section{How to cite}

de Sola Pueyo, J. (2021). 'Science in the media: the scientific community's perception of the COVID-19 media coverage in Spain'. JCOM 20 (02), A08. https://doi.org/10.22323/2.20020208. 